\title{
BRENTANO ON SCIENTIFIC PHILOSOPHY AND POSITIVISM*
}

\author{
BRENTANO SOBRE FILOSOFIA \\ CIENTÍFICA E POSITIVISMO
}

Flávio Vieira Curvello

https://orcid.org/0000-0001-9072-4472

fv.curvello@hotmail.com

Universidade Federal do Rio de Janeiro, Brasil

\begin{abstract}
In this paper, I analyze Brentano's fourth habilitation thesis, according to which the philosophical method should be none other than the natural scientific one. The meaning of this thesis can be initially assessed through an examination of Brentano's views on the relationship between natural and human sciences. His arguments for methodological unity in this debate show that he actually argues for an overarching idea of scientific knowledge, which is not restricted to the fields already recognized as scientific, but which can also be applied to philosophical domain. A fuller comprehension of that idea is provided by Brentano's writings on Comte's positivism.
\end{abstract}

Keywords Epistemology. Positivism. Natural sciences. Human sciences. Psychology.

RESUMO No presente artigo, analiso a quarta tese de habilitação de Brentano, de acordo com a qual o método da Filosofia tem de ser aquele da ciência natural. O sentido desta tese pode ser abordado inicialmente por meio de um exame da perspectiva de Brentano acerca da relação entre as ciências

* Article submitted on 13/08/2020. Accepted on 05/03/2021. 
humanas e naturais. Seus argumentos em favor de uma unidade metodológica neste debate mostram que ele está efetivamente argumentando por uma ideia omni-abrangente de conhecimento cientifico, que não pode ser restrita aos campos já reconhecidos como cientificos, mas que pode também ser aplicada ao domínio filosófico. Uma compreensão mais robusta dessa ideia é oferecida pelos escritos de Brentano acerca do positivismo de Comte.

Palavras-chave Teoria do conhecimento. Positivismo. Ciências naturais. Ciências humanas. Psicologia.

The purpose of this paper is to provide an interpretation of Franz Brentano's views on the scientific character of philosophy and how it relates to positivism. It is already widely known that Brentano was strongly influenced by Auguste Comte's approach to science and philosophy, and that many of his ideas both on the definition and the practice of scientific philosophy are to be understood within the framework of that influence. (Albertazzi, 2006, p. 14; Binder, 2017, p. 16; Gilson, 1966, pp. 432-433; Haller, 1988, p. 23; Ingarden, 1969, pp. 462-463; Münch, 1989, pp. 36-37; Schmit, 2002, p. 291; Simons, 2000, pp. 70-71, 79) As a matter of fact, in recent years current Brentanian scholarship has increasingly devoted more attention to this topic, providing us with some helpful analyses and emphasizing its importance and systematic role in the interpretation of Brentano's work (Benoist, 2011; Brandl, 2018, pp. 42-50; Fisette, 2018, pp. 76-77; forthcoming; Huemer, 2018; Ierna, 2014a; 2014b, pp. 545, 547; Porta, 2018, pp. 337-340; Rollinger, 2012, p. 278; Savu, 2019, pp. 47, 49-51; Schaefer, 2013, pp. 551-552; Tănăsescu, 2017; forthcoming). Such contributions are for the most part successful in showing how many fundamental epistemological and methodological convictions of Brentano's psychology are indebted to that heritage. Brentano's main work in this area, his "Psychology from an Empirical Standpoint" (1874), is a paramount example of those convictions, but they are also clearly stated in later works, such as his lectures on "Descriptive Psychology" (1890-1891). ${ }^{1}$

If we also consider how widespread Brentano's views on scientific philosophy became in $20^{\text {th }}$ century thought, the relevance of taking a closer look at them become even clearer. Among his students there were different 
approaches to the general idea of scientific philosophy that certainly depart from Brentano to a greater or lesser extent, but which can still be traced back to him. A well-known example of that is provided by Edmund Husserl's ideas on philosophy as a 'rigorous science'. Another example can be found in Carl Stumpf's visions on the relationship between experimental and descriptive research in psychology and their contributions to philosophy. Closely related to Stumpf's perspective are the methodological novelties of the Berlin School of Gestalt Psychology (Simons, 2000, p. 79; Schaefer, 2013, p. 543; Spiegelberg, 1965, p. 54; 1972, pp. 5-7, 67-69). Therefore, a better understanding of Brentano's position promises not just a deeper glimpse into his own work, but also an engagement with the wider historical and theoretical problems concerning his intellectual legacy.

This paper will only be concerned with the first aspect of this twofold way of seeing the importance of clarifying Brentano's thoughts on scientific philosophy. It will attempt, therefore, to contribute to the current debate by providing a comprehensive understanding of those thoughts and sketching some of their consequences for the general interpretation of Brentano's works. In order to do that, I will first address the thinker's famous fourth habilitation thesis, which states that philosophical groundwork must be done in strict accordance with natural scientific methodology. The meaning of such a claim is to be assessed by reference to the lectures "On the Future of Philosophy" (1893) and "On the Reasons for Disencouragement in the Field of Philosophy" (1874), both edited in a posthumous volume under the same title as the former lecture. Here I will concentrate particularly on Brentano's debate with Adolf Exner about the relationship of natural scientific methodology with the human sciences. It is indeed in this deeply important, but rather neglected topic, ${ }^{2}$ that we find a lengthy argumentation by Brentano favoring the idea of a univocal method for science in general. Afterwards, I will address Brentano's interpretation of positivism by means of an analysis of his essay "Auguste Comte and the Positive Philosophy" (1869), as well as of his further manuscripts on the theme, which were also posthumously published and bear the same title as the essay. Here I intend to underscore the positivistic import on Brentano's ideas about that univocal scientific method. In doing so, it will be possible to outline a general picture of this fundamental aspect of Brentano's work and sketch some further thoughts on its overall importance.

2 To my knowledge, its only in-depth analysis is provided by Benoist, 2011. 


\section{The method of philosophy as a natural scientific method}

As stated above, the stepping stone for our discussion is laid in Brentano's "Habilitation Theses", submitted to the University of Würzburg in 1866 and defended by means of a disputatio. This small work consists rather of a compilation of the defended theses and does not provide any argumentation that substantiates them individually. It has, however, a very broad philosophical scope, addressing questions of method, ontology, metaphysics, natural theology, cosmology, psychology, logic, philosophy of language, ethics and aesthetics (Kraus, 1968, p. 165). Under inspiration from Comte's positivism, its fourth thesis states: "The true method of philosophy is none other than that of the natural sciences" (Brentano, 1968, p. 137; cf. Haller, 1988, p. 22). Such an assertion could perhaps give the misleading impression that what is here at stake is only a praise or a somewhat apologetic defense of experimental study in philosophy. That is: a defense of that kind of study which aims at a controlled observation of certain phenomena, at the identification of different physical agents which define the causal context in which such phenomena take place, at conferring some degree of mathematical formalization to the propositions resulting therefrom, etc. This is not, however, the case. In order to assess what Brentano meant in his fourth habilitation thesis, it is important to analyze his lecture "On the Future of Philosophy" (Kraus, 1968, p. 168; Fisette, 2018, pp. 78-79; Werle, 1989, pp. 94-95).

This lecture consists of a reaction to Adolf Exner's inaugural speech as rector of the University of Vienna and was delivered in 1892 to the Philosophical Society of the city. In his speech, Exner had addressed the famous problem of transposing the method of the natural sciences into the human sciences. He had argued against this transposition by favoring a fundamental methodological dissent between both fields. In many respects, his position is similar to that of a major figure in this debate, namely Wilhelm Dilthey. (Brentano, 1968, p. 9; Benoist, 2011, p. 132). ${ }^{3}$ Brentano's position in his lecture, on its turn, is diametrically opposed to that. It consists rather in rejecting any methodological dissent between natural and human sciences and in stating that 'scientificity' is something to be defined by univocal criteria regardless of what kind of phenomenon a given science may have as its proper subject (Brentano, 1968, pp. $3,8)$. According to Brentano, Exner's main arguments for his own perspective are essentially twofold: 
(i) The natural sciences - considered through the paradigmatic case of mechanics - clarify the fundamental laws of nature. From these most general and comprehensive laws, some secondary laws are drawn, which are then applied to the factual occurrences and make it possible for the scientist to explain them by deductive means. The research in human sciences, as opposed to that, tackle such complex and intricate phenomena, which are so nuanced and dependent on so many unclear preconditions that they could never be fully known or undergo any exact analysis. The methodological difference between both fields should, therefore, be respected if the researcher wanted to avoid any misrepresentation of phenomena through unsuitable approaches, which would obviously lead to false conclusions.

(ii) The phenomena of the human sciences are historical, whereas the natural phenomena lack any similar feature. They have no such thing as a 'past' which could have a bearing on the way a phenomenon presently occurs - i.e., by preserving some aspects of what it once was in its actual manifestation. They also have nothing like a 'future' which could shape the phenomenon in a similar way, determining how it occurs according to certain possibilities of development that are intrinsically more pressing than others. The method of the human sciences therefore needs to be different and attentive to the historicalpolitical context in which the analyzed phenomenon takes place. Only the examination of such context could allow the researcher to understand that the present phenomenon is by no means absolute, but rather determined in its concrete meaning by those two extremes of the historical continuum (Brentano, 1968, pp. 30-31, 32, 35; Benoist, 2011, p. 132).

Exner understands, therefore, the natural sciences through the criteria of exactness and non-historicity and the human sciences, in contrast, through the criteria of inexactness and historicity. This is how he tries to substantiate the methodological dissent. Brentano is radically opposed to this perspective and both arguments it is based upon. He shows that they rely on erroneous assessments of the respective scientific domains, which should rather be characterized by methodological unity.

Against (i), Brentano claims that even though the phenomena of the human sciences are indeed complex and characterized by so many preconditions that can hardly be specified, this is no distinguishing feature between them and the natural phenomena. There are also several occasions in which the knowledge of the various preconditions of a natural phenomenon is considerably impaired. The relations such preconditions have to each other cannot be analyzed systematically enough, so that the deductive connections between particular occurrences and natural laws are rigorously identified and displayed. 
Actually, on a closer look, every natural phenomenon can be said to face such complications. It is rather just the case that the natural sciences are sometimes able to examine them more accurately, though sometimes not. However that may be, they are still far from being as effective as Exner claims.

Brentano offers us a great deal of examples of that in different natural scientific fields - e.g., the laws that determine the crystallization of different chemical compounds, which take different shapes when they change their physical state; the difficulty of understanding the development of a living cell merely through physical-chemical principles; the radical particularization of pathologies, which always depend upon the individual constitution of the affected organism; etc. The natural scientific task, therefore, is not as simple as Exner intends it to be. It requires the researcher to have enough flexibility to be mindful of the concrete, actual character of the investigated object. He must carefully adapt his approach to the materiality of the object, and not simply attempt to deduce explanations for particular phenomena from principles already deemed to be valid. Thus, Brentano states that nothing could better guide the researcher of the human sciences in his consideration of their complex phenomena than the way natural science proceeds, adapting its methods to the concreteness of the analyzed problem (Brentano, 1968, pp. 32-35; Benoist, 2011, pp. 132-134; Porta, 2018, p. 338).

Against (ii), Brentano introduces two arguments. The first states that (ii) would become a petitio principii as soon as (i) was refuted. The fundamental problem is not the difference between the phenomena of the natural sciences and those of the human sciences, but the possibility of consistently dealing with them through a univocal method. The difference between those phenomena is actually quite obvious, but it does not entail a special methodology for each field. If (i) were valid, there would be a reason for assuming the methodological difference and searching for further signs of it. Since (i) was rejected, however, (ii) is reduced to a mere remark on the difference of phenomena and an additional, unfounded assertion of the methodological difference. Such an attempt to defend this perspective, therefore, takes for granted what still must be argued for.

Brentano's second argument against (ii) makes the case that assuming historicity to be a distinguishing feature between the phenomena both of the natural and the human sciences is a mistake. Natural phenomena are processual and have their own historicity. According to it, a present fact is related to primitive stages of its own development, and it tends as well to certain future stages which restrict its possibilities of further differentiation. Brentano also offers many examples of that, such as embryological studies or the process 
of body maturation and aging, the development of pathological conditions, a recurring epidemic disease, etc. Exner's view of the natural sciences is again narrow and flawed. He overlooks how different natural scientific fields deal with deeply complex phenomena, which can hardly be traced back to all its different causes and which take place in a wide, multi-layered continuum of natural processes. The natural scientist's approach to such phenomena and his ways of handling their complexity also serve here as a model for the efforts of human science. The fundamental methodological unity of science must, therefore, be preserved (Brentano, 1968, pp. 35-37, 44; Benoist, 2011, pp. 134-137).

The two arguments introduced by Brentano show what is really at stake in his case for the applicability of the natural scientific method in the human sciences. For the main part, they show what Brentano means by 'natural science' and to what extent the intellectual disposition required by that field may be of general benefit. As stated above, Brentano's arguments are not about a sudden conversion of the problems of human science into experimental ones (Gilson, 1966, pp. 420, 430-431). They rather aim at retrieving something more fundamental to the cognitive attitude of the natural scientist - something which lays the ground for his different concrete approaches to nature, determining his many practical ways of observing its entities and processes, analyzing the observed data, drawing and reassessing conclusions, etc. Such an intellectual point of departure would consist of a radical commitment to grasp the fact of interest and describe the different ways it occurs; to achieve a most comprehensive view of the regularities therein; to continuously conform the observation to the requirements of the fact, so that the way of approaching it does not become a way of covering it up or deforming its nature, but rather of clarifying it; to always focus on carefully defined issues instead of overarching ones, even though the progress of the research will consequently be slower and more laborious (Brentano, 1968, pp. 12-14). The representative of the human sciences must precisely follow these principles of investigation whenever he deals with the phenomena proper to his area. What is here in question is the definition of a fundamental idea of scientificity, which would have to be assumed and applied whenever a proper scientific study is to be conducted. Thus, according to Brentano, to defend the methodological difference between natural and human sciences is not to recognize that the scientist's approach to his objects of investigation is always defined through this set of basic dispositions. They frame the cognitive attitude of anyone who rigorously desires to know 
something. (Brentano, 1968, p. 45; Benoist, 2011, pp. 134, 138, 147; Ierna, 2014a, 2014b, pp. 545-546; Willard, 1998, p. 37; Tatarkiewicz, 1973, p. 218) ${ }^{4}$

Hence, Brentano's case against Exner clearly exceeds the relationship between natural and human science, consisting rather in the postulation of an idea of scientific knowledge in general. It is precisely because of its general character that his arguments allow us to understand the fourth habilitation thesis. To say that the method of philosophy is none other than that of the natural sciences is to say that philosophy is also encompassed by this idea and must be described in the same terms as any other scientific field. This is what Brentano explicitly states in his inaugural address at the University of Vienna in 1874, entitled "On the Reasons for Disencouragement in the Field of Philosophy". According to Brentano, there would be no doubt about the role of experience as the only teacher in philosophical matters, and it is the task of the scholar who deals with them to proceed like any other scientific scholar - i.e., to progress step by step, slowly clarifying the main problems of his area, gradually undoing the fundamental obstacles to their comprehension and achieving modest, but sound results (Brentano, 1968, p. 85; Haller, 1988, pp. 22-23, 25-26). The further information Brentano provides on this exemplary scientific procedure strikingly attests the relevance of positivism to his perspective. The natural scientist understands the impossibility of intuitively grasping the 'how' and the 'why' of natural processes. He focuses, instead, on natural appearances and on their concrete modes of succession. By identifying the similarities pervading its different cases, he recognizes the general, unchangeable relations between the appearances, i.e., the laws that rule their factual connections. Thus, his task would be that of arranging 'particular facts' as specific cases of 'general facts', which would consist precisely in these relations or laws mentioned above (Brentano, 1968, pp. 89-90; Fisette, 2018, pp. 78, 94; Tănăsescu, 2017, pp. 335, 342-343, 352-353, 358).

The philosopher should behave the same way in what concerns those investigative interests which may reach beyond his intuitive capacities, since he is also denied any kind of immediate apprehension of the essence of the objects he analyzes. Like the scientist, he must primarily devote himself to the examination of facts, to the clarification of the laws that rule them, and to the objective correlation between these two instances. Thus, he will be able to explain facts already known and foresee how facts yet unknown can possibly

4 The defense of such unity does not mean that the attempt to employ the natural scientific method in the human sciences is free of problems. A comprehensive list of these problems is provided in Appendix XII to the presently analyzed lecture - Brentano, 1968, pp. 75-81. 
happen. In short, the philosopher must give up any intentions of intuitively accessing the "domain of what is utterly inapprehensible" and focus on the factuality, employing a method "corresponding to the things" (Brentano, 1968, pp. 95-97). ${ }^{5}$

\section{Positivism and the definition of the scientificity of philosophy:}

The previous section has shed some light on the already mentioned influence from Comte's positivism over Brentano. Indeed, Comte figures, as mentioned earlier, as a privileged interlocutor in Brentano's defense of a methodological unity of science, in which philosophy takes part. The relationship between both thinkers can be properly understood through the analysis of Brentano's essay "Auguste Comte and the Positive Philosophy", published in 1869 in the journal Chilianeum, and of his manuscripts of the same period, edited under the same title as the essay and published in the posthumous volume "History of Modern Philosophy". In both sources, Brentano addresses Comte's thesis that the development of the human intellect in every domain of knowledge obeys a fundamental law that necessarily divides its progress into three stages. ${ }^{6}$

(i) In the 'theological' or 'fictional' stage, the investigative interest is directed to the intrinsic nature of things and to the efficient and final causes which act upon them. The explanation of natural occurrences put forward as a postulate the existence of an amount of free and rational supernatural forces, which would rule the natural world and the course of its events. Such an explanation, however, would be devoid of exactness and would also interpret those forces as somehow akin to mankind and characterized by some traits that closely resemble our own. Thus, the very way in which the divine power is here understood reveals a fundamental inclination to anthropomorphism (Brentano, 1869, p. 19; 1987, pp. 246-248, 250, 262; Comte, 1830, pp. 4-5, 9-13; 1844, pp. 2-8; Fisette, 2018, p. 88; Münch, 1989, p. 37; Tănăsescu, 2017, p. 337).

(ii) The 'metaphysical' or 'abstract' stage serves only as an intermediary phase in the progress of human intellect. In such a stage, the supernatural forces of the theological stage are replaced by abstract natural forces, which are

5 On the impact of such a conception of philosophy on Brentano's disciples, cf. Baumgartner, 2003, pp. 5-6; Binder, 2017, p. 16; Brentano, 1968, p. 30; Husserl, 1987, pp. 305-306, 309-310; Stumpf, 1919, p. 88; 1924 , p. 208; Werle, 1989, pp. 92-94.

6 Brentano delivered a cycle of public conferences on Comte and his positivism in Würzburg, 1868. He planned to write a series of seven essays on Comte, but only the one from Chilianeum was published. The manuscripts that are here analyzed seem to be a sketch for further essays (Hedwig, 1987, p. 361; Schmit, 2002, p. 292). For further historical information on this topic, cf. Fisette, 2018, pp. 73-82. 
conceived as the actual and most eminent components of reality. They consist of hypostasized entities or abstractions, which constitute the things existing in the world, defining their real consistency, the properties they may exhibit, the processes in which they participate, etc. It is a perspective in which mere concepts of human understanding are taken for real entities, which inhabit concrete things and make them what they are (Brentano, 1869, p. 19; 1987, pp. 247, 251-252, 262-263; Comte, 1830, pp. 4-5, 13-14; 1844, pp. 8-12; Fisette, 2018, p. 88; Münch, 1989, pp. 37-38; Tănăsescu, 2017, p. 337).

(iii) In the 'positive stage', human intellect reaches its peak of development, recognizing the impossibility of an absolute knowledge of natural things and occurrences, as well as of their origins, intrinsic causes and possible ends. Instead of that, such intellect is concerned only with the methodical use of observation and the consequent rational inference of the real laws that rule them - i.e., of their unchangeable relations of succession and similarity. Scientific explanation, therefore, would consist precisely in the clarification of the relations between particular and general facts. Put another way, it would consist in grasping and outlining the connection between observed facts. (Brentano, 1869, pp. 18-19, 25; 1987, pp. 247-248, 254; Comte, 1830, pp. 4-5, 14-17; 1844, pp. 12-22; Fisette, 2018, pp. 85, 88; Münch, 1989, p. 38; Tănăsescu, 2017, p. 338) The affinity between this definition of scientific knowledge and the one introduced by Brentano in "On the Reasons for Disencouragement in the Field of Philosophy" is quite obvious. Comte's views are literally retrieved in this lecture even though the thinker himself is not quoted.

According to Comte, all stages tend, in their progress, to unify their explanatory principles. Thus, the theological stage would improve its theoretical consistency when it no longer admits a plurality of divine forces, to which natural phenomena should be traced back, but rather only one force, paying regard to a single providence. The metaphysical stage, on its turn, would improve itself while the different abstractions it hypostasized were gradually understood no longer as autonomous entities, but as moments of one greater, all-encompassing identity, i.e., 'nature' itself. Likewise, the positive stage could aspire to coordinate particular facts no longer under a large number of general facts, but under a single and most fundamental one, which would explain all laws of succession and relations of similarity among natural phenomena. A candidate for such position would be the astronomical law of gravitation. Brentano points out, however, that this tendency towards unification of explanatory means does not apply to the positive stage in the same way it does to both primitive stages. He emphasizes the fact that Comte sees the problems involved in the identification of such a primordial law. Actually, 
both the systematic structuring of positive philosophy and the achievement of its objectives do not depend at all on such a unity, but rather on another, more concrete one: the unity of method (Brentano, 1987, p. 248; Comte, 1830, pp. 15-16; 1844, pp. 22-24. Tănăsescu, 2017, p. 346).

The status of positive science would require nothing more than conducting investigations according to the aforementioned principles. It implies a declination of any interest in intrinsic causes of phenomena, which cannot be directly apprehended by the investigator. And, instead of that, it implies the observance of the regularities of phenomena, from which their laws are derived (Brentano, 1869, p. 23; 1987, p. 252; Comte, 1830, pp. 15-16; 1844, pp. 12-14). According to Comte, therefore, any investigation in any possible field of knowledge that raises the claim to be science must take heed of these principles. Such a standpoint is, once again, clearly related to that of Brentano, both caring to defend the general characteristics of the scientific method and not accepting anything as science which somehow diverges from those references and intends to be 'another way to work scientifically.'

Brentano introduces, however, a peculiar interpretation of Comte's views on the notion of cause. He argues that the thinker would not doubt the existence, but rather the cognoscibility of causes. Strictly speaking, Comte would admit the thesis that nothing in the natural world happens without an efficient cause. However, our possibilities of understanding the relationship between such a cause and the effects it brings about would be limited, since it depends upon experience. In order to understand that relationship, we would have to repeatedly experience the connection as it factually manifests itself and draw by induction a conclusion, which states with certitude that it is indeed a general fact. However rigorous and systematic the application of such a procedure might be, it would not be able to keep questions about the 'why' and the 'how' of that relationship at bay. An example makes the thesis clearer. Let us consider a moving body striking against another body at rest, and that it does so in such a way that it is able to bring the latter into motion as well. According to Brentano, Comte would not say that it is impossible to identify a causal relation here, in which the collision of the first body against the second one is responsible for what occurs to the latter, to which the movement is transmitted. This could be repeatedly verified by exercising a controlled observation which reproduces the general conditions of occurrence of that phenomenon. The observer would, then, acquire a certain knowledge grounded on facts. Such knowledge, however, would never be sharp and deep enough to disclose why bodies behave the way they do under the described conditions. We would never have such a clear 
comprehension of those bodies and their properties, which would show us the ultimate reason why that phenomenon is the case exactly the way it is.

The knowledge of causes would never be as clear as, say, the knowledge of relationships between mathematical concepts. Let us here consider, e.g., the analysis of the relation between the numbers 2 and 4 . The mere reflection on the concepts of the respective numbers would show it to be immediately understandable that the first of those numbers equals half of the second one. Further questions on the validity of this state of affairs do not come to our minds whenever we state that. We are not prompted to ask whether it is indeed a categorical validity or whether the extent of such validity should still be further determined. Rather, such validity is found a priori in the examined concepts. ${ }^{7}$ When we strive to know causes, however, we never see phenomenal connections as they are in their innermost character. We never pierce into its real structure and reach such an understanding of its essence, which would show us, independently of all factual experience, the ultimate reason why the connection is what it is. There is no such thing as complete knowledge of the concepts involved therein, nor any subsequent deduction of categorically valid states of affairs related to those concepts. The intrinsic nature of the causal principle always remains hidden. A certain knowledge of the cause would therefore be possible, but in a limited way and without an understanding of its utmost 'how' and 'why' - i.e., without conceiving of any intuition of the causal connection itself (Brentano, 1869, pp. 26-28; 1987, pp. 255-258; Fisette, 2018, pp. 85-86; Münch, 1989, pp. 39-40; Schmit, 2002, pp. 292-294; Tănăsescu, 2017, pp. 338-339).

Brentano's aim with his interpretation becomes more explicit when he criticizes the terms Comte employed to name the two early stages of knowledge. According to Brentano, the term 'theology' does not effectively apply to the cognitive orientation described in the first stage, which was centered on the idea of explaining natural phenomena with the aid of somewhat human-like divine forces. He substantiates his claim by providing us with some relevant reflections on the origins and development of theological thought in far earlier stages of our history. According to Brentano, the first theological interpretations of the world consisted in a projection of ideas primitive people had about their own bodily conditions. They considered their power to voluntarily move their bodies and to physically interact with the surrounding world in a varied set

7 Brentano argues for an interpretation of mathematics as an essentially analytic science, rejecting, therefore, Kant's interpretation of it as synthetic a priori discipline, which proceeds through construction of concepts. Brentano's standpoint is explained in his posthumously published essay Down with the Prejudices! (Brentano, 1970 , pp. 7, 47-51). For his early views on mathematics, cf. lerna (2012). 
of practical situations. Thus they understood that their will was the efficient precondition to that sort of effect. On that basis, they came to the idea that every further effect in the natural world should as well depend upon some kind of will, which would account for the effect as a whole - setting beforehand its underlying meaning, purpose and inherent reason. In the most primitive stages of theological thought, that belief led to simple animism and hylozoism. In its next developments, however, it led to different apprehensions of the divine both in polytheistic and monotheistic perspectives. There we see the emergence of the main trait of the theological stage that was already addressed above: the explanation of natural occurrences through the agency of free and rational supernatural forces. According to this, a theological worldview would come about, in short, from an analogy between our ability to control our bodies by will and how the world itself works (Brentano, 1869, pp. 20-21).

That is why Brentano follows John Stuart Mill in his monograph "Auguste Comte and Positivism" (1865), and states that it would be more appropriate to speak of a 'personal' or 'volitional' stage. He suggests also to name it a 'mode of explanation having recourse to fictional persons' (personenfingierende Erklärungsweise) ${ }^{8}$ (Brentano, 1869, pp. 32-33). Beyond Comte's perspective and in its legitimate meaning, theology would rather consist of a systematic, rational investigation of the divine being, of the evidences of its existence, (to a certain extent) of its nature and attributes, of revelations, etc., providing also the grounds for the discussion of the immortality of the human soul (cf. Krantz Gabriel, 2017; Schaefer, 2017).

In a similar way, Brentano also claims that a rigorous depiction of metaphysics would as well bring similar problems to Comte's ideas about an intermediary stage in the progress of human knowledge, showing the inadequacy of the expression 'metaphysical stage'. Understood in the Aristotelian sense, i.e., as the science of being qua being, metaphysics reaches far beyond Comte's restrictive characterization of that stage and of its questionable ways of explaining phenomena by the identification of their underlying entities. The alternative name introduced by Comte himself, i.e., 'abstract stage', would be more suitable, since the essence of this stage is the hypostatization of abstractions. Also here Brentano suggests another expression for it, namely the 'mode of explanation having recourse to fictional entities' (entitätenfingierende Erklärungsweise) - which relies on the fact that the term Entitas in medieval 
philosophy often assumed the same meaning Comte addressed in his definition of the second stage (Brentano, 1869, pp. 33-34).

Both of Brentano's terminological remarks attempt at specifying what he believes to be the actual meaning of Comte's claims, thereby avoiding misleading understandings of the 'real consistency' of his theories. Seen in light of their purely conceptual merits, they are, in Brentano's view, very pertinent, since any scientific approach would have to avoid investigative interests which overstep the natural constraints of our capacity to know (Brentano, 1869, pp. 33-34; 1987, pp. 262-263; Fisette, 2018, pp. 83-84; Kastil, 1951, p. 28; Münch, 1989 , p. 49). Brentano's greatest objective, however, is to show that positive science is not opposed to theology and metaphysics in their legitimate versions. Quite the contrary: science could even work together with both disciplines, if the philosophical inquiry which addresses theological and metaphysical issues assumed the advocated scientific character - which must always constitute the utmost character of proper philosophical practice (Gilson, 1966, p. 433; Schmit, 2002, p. 294).

But one could reasonably ask here, when confronted with this latter claim: it is indeed possible to make sense of a metaphysical investigation which is underpinned by Brentano's empirical approach, but how could that be the case for theology at all? How could someone strive for sound, rigorously inductive, logically consistent, experience-based results in the investigation of divine issues? How could theology work together with natural science? In the published version of his manuscript, Brentano tries to shed some light on those problems by sketching out some basic situations in which a theistic stance could hinder scientific thought, as well as by showing us ways of overcoming these hindrances. From his general remarks, two seem to be the most significant for his theoretical purposes, and they are the ones I address next. The theistic stance could be a problem for science:

(i) If it implied the assumption of our ability to grasp the essence of God as the first and most universal cause and, by means of analytical thought - i.e. a priori - to infer the possible effects of that cause (Brentano, 1869, pp. 28-29).

(ii) If it implied a radical abridgement of scientific endeavors, leading back every plausible question concerning the world's phenomena to the will of an almighty Creator. In such a scenario, everything should find an 'explanation' in the idea that each and every occurrence of the world is 'what it is' and 'the way it is' because God wants it to be so. Brentano points out that this perspective would render science impossible, since it would immediately jump from the most local and particular effects up to the first and most eminent cause of everything-completely ignoring that between them there is a considerable 
number of intermediary causes, which are not subdued to any investigation whatsoever (Brentano, 1869, pp. 31-32).

Brentano reacts to that, however, as a disfigurement of a rigorous and rational theism. Against (i), he reminds us that there is actually no requirement to any kind of knowledge to enable us to see into the essences of phenomena. Such a thing does not happen even when we analyze the most trivial physical occurrences. Then, it is certainly also impossible when we try to investigate the highest and farthest determinations of the world. Brentano defends the idea that we are able to have a certain knowledge of God, but only by approximative means - i.e., in degrees. Such a partial knowledge would be provided, on the one hand, by negative statements - i.e., by stating what God is not, as negative theology does - and by analogies with natural phenomena in general-i.e., by a fact-centered investigation of physical, empirical reality which leads, by $a$ posteriori means, to the conclusion that such a reality must rely on an original, transcendent power (Brentano, 1869, p. 29; cf. Krantz Gabriel, 2017, p. 148; Schaefer, 2017, pp. 218-220). ${ }^{9}$

Against (ii), Brentano states that it is also no necessary consequence of theism. As a matter of fact, this stance may well admit the existence of a primordial cause in the figure of God and, nonetheless, without bringing any problems to it, understand that there are plenty of links in the causal chain that leads from God to the most particular effects we may observe in the world. And on that basis, it may also recognize the importance of diligent scientific investigation of those links. The fact that God is the ultimate explanation for things in our world does not entail that there is no work left to be done for science. On the contrary: there is indeed such a work and it consists precisely in the investigation of all levels of causal determinations that lead from God down to concrete things (Brentano, 1869, p. 32).

Brentano's interest, therefore, is to show that a theistic stance does not necessarily imply such intellectual decisions which could doom scientific inquiry from the very start. In any case, here is not the place to delve further into his ideas on theology or on the relationship between religion and philosophy - which are, for their own sake, very important to understand Brentano's philosophy as a whole. It is enough for the purposes of this essay just to

9 Schaefer (2017) provides us with a very good summary of Brentano's argument for God's existence, which refutes the classic a priori forms of ontological argument in the history of philosophy. Instead of that, Brentano intends to show that it is possible to be sure of God's existence by means of a thorough examination of consciousness and empirical, physical reality. His arguments are, therefore, as quoted above, a posteriori and start with the observation of phenomena in the created world in order to slowly progress to its transcendent Creator. 
outline some of his basic ideas on those issues and refer to sound and already accessible, specialized research on them. So the present analysis will not be led so far afield. ${ }^{10}$

Now, as we see above, Brentano argues against Comte, although he understands his own argument as essentially favorable to him and the radicalization of his thought (Brentano, 1987, p. 264; Schmit, 2002, p. 294; Tănăsescu, 2017, p. 345). His peculiar way of referring to Comte, therefore, does not only help us clarify the fundamental meaning of his thesis about the scientificity of philosophy, but also the fact that it considers metaphysics and theology to be legitimate philosophical disciplines. To exercise the scientificity of philosophy, then, is to heed the strict delimitation of the facts to be investigated, to develop theories cum fundamento in re, attentive to their possible counter-examples and to the fundamental adaptability of concrete methods of investigation. It also requires us to neither overlook the facts in favor of speculation, nor get ourselves involved with the assumption that essential traits of phenomenal connections are knowable as such, since all we can directly deal with are the connections themselves. Lastly, it also means ensuring that theological and metaphysical problems have their place in philosophy, since they are compatible with the principles of a scientific philosophy.

\section{Concluding remarks}

The foregoing analyses were able to shed some light on Brentano's idea of scientific philosophy. It was possible to make sense of his claim in his fourth habilitation thesis that philosophy should only be practiced on the basis of natural scientific methodology. As we have seen, it has nothing to do with the thesis that the experimental approach should be the only eligible way of substantiating theoretical claims in general. Instead, Brentano's view is based on a deeper analysis of that which lays the ground for the plurality of concrete means of research in natural science and enables each one of them to be justifiably designated as scientific. Actually, it is quite clear that the various fields of natural science do not proceed in the same way when they analyze the phenomena of their interest. The different devices used in astronomical observation, for instance, are not the same as those used in the observation

10 Besides that, an optimal example of how metaphysical and theological issues can be associated with scientific investigation is provided by Brentano's recently published lecture "The Laws of Interaction of the Natural Forces and Their Meaning in Metaphysics" (1879). There he addresses philosophical problems entailed by the second law of thermodynamics, viz., the question on the origins of the natural world. 
of microscopic physical phenomena or chemical reactions. The very way observation must be conformed to each one of those technological resources makes it clear that the concrete process of observation is quite different in each one of those cases. Even if we focus only on one natural scientific field, the specific ways of investigating its different phenomena will be quite different from each other. Psychological research provides us with clear examples: the psychophysics of sensations cannot be investigated with the same resources as the observation of psychopathological phenomena. These two kinds of investigation are different from that of the anomalies of sense perception due to acquired or congenital bodily impairment. All of them, at last, are different from an investigation on animal behavior and intelligence (Brentano, 1874, pp. 45-52).

What entitles us to label all those different modes of investigation as natural scientific ones? There must be a foundation for such a claim - i.e., some kind of general cognitive disposition on the basis of which different concrete scientific approaches to phenomena are possible. This is the crucial point of Brentano's discussion. When he mentions 'natural science' in his fourth habilitation thesis, he mentions this core of natural scientific method, which makes it possible for all those investigations to be scientific. We can grasp Brentano's interest more efficiently if we avoid a rather trivial terminological problem that crops up in this discussion. If we consider the usual way of employing the word 'method', its meaning is easily assimilated to that of, say, a 'concrete way of conducting an investigation', a 'series of practical steps someone should take in order to correctly understand something' - like the ones mentioned above. According to that, psychophysics would have its own method; the psychological examination of sensory deficiency, on its turn, another one; the clinical examination of psychopathology and the observation of animal behavior, still other ones. But Brentano does not address this trivial comprehension of the word when he speaks of natural scientific method. He addresses, instead, the unitary intellectual basis upon which all those procedures must depend if they should count as scientific. That is the meaning of 'natural scientific method' in the fourth habilitation thesis: the unitary ground of all scientific practice and not the diversity of their concrete procedures.

We have also seen that this natural scientific method consists in giving the facts scrupulous attention and searching for their boundaries with rigor; in conforming the modes of observation to their demands; in slowly progressing through the identification of their relations of similarity and succession; in avoiding any kind of speculation or investigative interest which exceeds the factual contexts observed; etc. It is precisely such a fundamental set of injunctions that is said to be constitutive of scientific knowledge itself guiding the activities 
of those fields traditionally labeled as natural sciences, human sciences and philosophy as well - even in its most abstract kinds of investigation, such as the metaphysical and the theological ones. It is precisely in Brentano's description of the general character of natural scientific method that we see the relevance of his interlocution with positivism. Many of Brentano's claims in his lectures considered in the first section of this paper are directly related to Comte's claims as we have seen in the second section. It is not always the case that Brentano explicitly speaks about such influence, but in a systematic point of view, the positivistic flair is very clear. Comte's case against speculation and attempts to investigate things beyond our natural cognitive constraints, his thorough emphasis on fact-based knowledge of generalities, and mostly his views on the methodological unity of science all come to Brentano's inheritance.

As stated in the introduction to this paper, such a fundamental thesis on the method of philosophy can be stated in many points of Brentano's known works. We see in some of these works not just a clear application of those principles, but also, to a certain extent, their completion. In his "Psychology from an Empirical Standpoint", e.g., Brentano emphasizes the supranational, unitary character of a legitimate scientific psychology, which he aims at introducing. He develops his own psychological theories by means of a thorough analysis of experience drawing conceptual conclusions on the basis of clear and well-delimited empirical examples. He also employs an Aristotelian dialectical approach in such analysis, in which the opinions of a psychological, philosophical tradition about the investigated phenomena are critically examined. Those opinions that disagree with experiential data are rejected, whereas those that do agree are further investigated so that it becomes clear what a role they can possibly play in a new theoretical assessment of those phenomena. Moreover, he reflects on the way scientific resources such as induction and deduction work in psychological research, stressing mostly the former one and its importance for discrimination and classification of mental phenomena as well as the identification of their laws of succession (Brentano, 1874, pp. vi, 55, 93-97, 102-103). ${ }^{11}$

In his lectures on "Descriptive Psychology", Brentano also clearly works according to this methodological standpoint. His approach to psychology in that work may perhaps suggest otherwise since he explicitly thematizes descriptive psychology or psychognosis as a pure and exact branch of psychology. Such a branch investigates mental phenomena only by means of inner perception and has a foundational role in its relation to the other psychological branch, namely, 
genetic psychology. Along the well-known lines of Brentanian tradition, descriptive propositions should lay the ultimate theoretical basis upon which genetic, explicative propositions depend, if they aim at full-fledged justification. The other way round, descriptive psychology can only receive some assistance from genetic psychology when it comes: (i) to the merely technical support of descriptive studies - e.g., evoking, by experimental means, some phenomena that the psychologist wants to investigate descriptively; extending those phenomena in time; optimizing the conditions in which phenomena can be contrasted with each other; etc. -; and (ii) to explanations of psychological conditions which inner perception cannot investigate - e.g., experimentally induced optical illusions, such as the famous 'Zöllner illusion' (Brentano, 1982, pp. 1-9). This explanation can perhaps lead us to think that such a purely intuitive psychology as the descriptive one has very little, if anything, to do with the method of natural sciences. That is, however, not the case. Brentano does not seem to ever have abandoned this underlying idea (Gilson, 1966, p. 430). In "My Last Wishes for Austria", his farewell text to Austrian University published few years after those lectures, he still defends explicitly his views on method (Brentano, 1895, p. 32). And his descriptive psychology can indeed be understood within this framework.

Brentano introduces a detailed psychognostic method in his lectures, which comprehends five sequential steps: experiencing, noticing, fixing, inductive generalization and deduction. His explanation of each one of these steps is not to be summarized here since it would lead us too far astray. But it actually provides us with a very good example of his natural scientific approach insofar as: (i) it accurately describes the psychological activities implied in each one of those steps; (ii) it considers other psychological activities with which they can possibly be confused and excludes them from discussion, so that the conceptual delimitation of each step of the method is achieved with clarity and precision; (iii) it thoroughly explains the epistemological character of each step, defining if it is fallible or not; (iv) for those steps which prove to be epistemically privileged and not fallible, it identifies their main sources of poor performance; (v) for those steps which are indeed fallible, it identifies their natural sources of mistake, sketching also the possibilities of avoiding them; (vi) it provides us with more tangible, not merely programmatic views on the assistance descriptive psychology can receive from the genetic one; etc. Even though this paper is not the right place to get a deeper glimpse on all these issues, they must be nevertheless briefly mentioned since they are the clearest points of Brentano's argumentation in his lectures which illustrate his fourth habilitation thesis and his strict scientific approach to psychology. They 
are nothing but results of the cautious, slowly progressive, fact-centered, nonspeculative approach we already know.

The lectures on "Descriptive Psychology" and the "Psychology from an Empirical Standpoint" show us, therefore, how Brentano has put his fourth habilitation thesis into effect. These incipient remarks above should suffice to make it clear. They should also show us that the philosopher develops his ideas on scientific approach even further incorporating into them more accurate discussions of other investigative resources, such as deduction, the dialectical examination of other theories and arguments of other thinkers, etc. Indeed, a very important example of this further development can be found on Brentano's treatment of induction as the fourth step of his psychognostic method. In his lectures on "Descriptive Psychology", he briefly explains some ideas on that special way of exercising induction, which he labeled as "induction in the broader sense' in his essay "Down with the Prejudices!" (Brentano, 1970, p. 74. Porta, 2018, p. 338). It consists, to sum up, in an alternative way of reaching for generalities on the basis of exemplary facts so that the cognition of those generalities is immediate and valid a priori.

There are, indeed, many ways to enrich and extend our knowledge of Brentano's take on scientific philosophy if we carefully analyze not only his programmatic works, but mainly those ones in which such philosophy is practiced. As mentioned in the introduction to this paper, there are also many ways in which we can take Brentano's perspective as a starting point and cast some light on the later approaches to scientific philosophy, which are historically connected to the Brentano School, so that we may also progress from a theoretical point of view and become more able to understand in clear and sober terms further aspects of Brentano's legacy. These are, however, subjects of future work.

\section{References}

ALBERTAZZI, L. "Immanent realism. An introduction to Brentano." Dordrecht: Springer, 2006.

BAUMGARTNER, W. "Le contenu et la méthode des philosophies de Franz Brentano et Carl Stumpf." Les études philosophiques, Vol. 1, pp. 3-22, 2003.

BENOIST, J. "Le naturalisme de Brentano". Revue Roumaine de Philosophie, Vol. 55, Nr. 1, pp. 131-147, 2011.

BINDER, T. "Franz Brentano: Life and Work". In: KRIEGEL, U. (ed.) The Routledge Handbook of Franz Brentano and the Brentano School. New York: Routledge, 2017. pp. 15-20. 
BLACKMORE, J. "Franz Brentano and the University of Vienna Philosophical Society 1888-1938”. In: POLI, R. (ed). The Brentano Puzzle. Vermont: Ashgate Publishing Company, 1998. pp. 73-91.

BRANDL, J. Brentano's renewal of philosophy: a double-edged sword. BrentanoStudien, Vol. 16, pp. 361-372, 2018.

BRENTANO, F. "Auguste Comte und die positive Philosophie". Erster Artikel. Chilianeum Blätter für katholische Wissenschaft, Kunst und Leben, Vol. 2, 1869.

. "Auguste Comte und die positive Philosophie". In: HEDWIG, K. (ed.) Geschichte der Philosophie der Neuzeit. Hamburg: Felix Meiner, 1987. pp. 246-294.

. "Deskriptive Psychologie". Hamburg: Felix Meiner, 1982.

. "Die Gesetze der Wechselwirkung der Naturkräfte und ihre Bedeutung für die Metaphysik”. Brentano Studien, Vol. 14, pp. 27-56, 2016.

. "Meine letzten Wünsche für Österreich.” Stuttgart: Cotta Verlag, 1895.

. "Nieder mit den Vorurteilen! Ein Mahnwort an die Gegenwart, im Geiste von Bacon und Descartes von allem blinden Apriori sich loszusagen". In: KASTIL, A. (ed.), Versuch über die Erkenntnis. Hamburg: Felix Meiner, 1970. pp. 3-113.

1874.

. "Psychologie vom empirischen Standpunkte". Leipzig: Duncker \& Humblot, "Über die Zukunft der Philosophie". Hamburg: Felix Meiner, 1968.

COMTE, A. "Cours de philosophie positive". Tome premier. Paris: Rouen Frères, 1830. . "Discours sur l'esprit positif". Paris: Carilian-Goeury et von Dalmont, 1844.

FISETTE, D. "Franz Brentano and Auguste Comte's positive philosophy". Brentano Studien, Vol. 16, pp. 73-110, 2018.

. "Introduction: Franz Brentano in Vienna". In: FISETTE, D. FRÉCHETTE, G. STADLER, F. (eds.) Franz Brentano and Austrian Philosophy. Vienna Circle Institute Yearbook. New York: Springer Verlag. Forthcoming.

GILSON, L. "Science et philosophie selon F. Brentano". Revue Internationale de Philosophie, Vol. 20 (78-4), pp. 416-433, 1966.

HALLER, R. "Franz Brentano, ein Philosoph des Empirismus". Brentano-Studien, Vol. 2, 19-30, 1988.

HEDWIG, K. “Anmerkungen des Herausgegebers”. In: In: HEDWIG, K. (ed.) Geschichte der Philosophie der Neuzeit. Hamburg: Felix Meiner, 1987. pp. 299-372.

HUEMER, W. "Vera philosophiae methodus nulla alia nisi scientiae naturalis est. Brentano's conception of philosophy as rigorous science." Brentano Studien, Vol. 16, pp. 53-72, 2018.

HUSSERL, E. "Erinnerungen an Franz Brentano". In: NENON, T. SEPP, H. R. (eds.), Aufsätze und Vorträge (1911-1921). Dordrecht: Martinus Nijhoff, 1987. pp. 304-315. IERNA, C. "Brentano and mathematics". In: TĂNĂSESCU, I. (ed.) Franz Brentano's metaphysics and psychology. Bucarest: Zeta Books, 2012. pp. 338-396.

. "La science de la conscience selon Brentano". In: C. NIVELEAU (ed.) Vers une philosophie scientifique: Le programme de Brentano. Paris: Demopolis, 2014a. 
[Online] Available at: http://books.openedition.org/demopolis/108 (Accessed on: 18th August 2020).

. "Making the humanities scientific. Brentano's project of philosophy as a science". In: BOD, R., MAAT, J. WESTSTEIJN, T. (eds.), The making of humanities, vol. 3. The modern humanities. Amsterdam: Amsterdam University Press, 2014b. pp. 543-554. INGARDEN, R. "Le concept de philosophie chez Franz Brentano". Archives de Philosophie, Vol. 32, Nr. 3, pp. 458-475, 1969.

KASTIL, A. "Die Philosophie Franz Brentanos. Eine Einführung in seine Lehre". Bern: A. Francke AG, 1951.

KRANTZ GABRIEL, S. "Brentano on the Soul". In: KRIEGEL, U. (ed.) The Routledge Handbook of Franz Brentano and the Brentano School. New York: Routledge, 2017. pp. 144-149.

KRAUS, O. “Anmerkungen des Herausgegebers”. In: KRAUS, O. (ed.), Über die Zukunft der Philosophie. Hamburg: Felix Meiner, 1968. pp. 145-183.

MÜNCH, D. "Brentano and Comte". Grazer Philosophische Studien, Vol. 35, pp. 33-54, 1989.

PORTA, M.A. "Brentano y el método psicológico". Síntese, Vol. 45, Nr. 142, pp. 327344, 2018

ROLLINGER, R. "Brentano's Psychology from an Empirical Standpoint." In: TĂNĂSESCU, I. (ed.) Franz Brentano's metaphysics and psychology. Bucareste: Zeta Books, 2012. pp. 261-309.

SAVU, B. "A sketch of the notion of decline in Auguste Comte. Common points with the corresponding Brentanian notion." Analele Universităţii din Craiova, Seria Filosofie, Vol. 43, Nr. 1, pp. 46-67, 2019.

SCHAEFER, R. "Brentano's Philosophy of Religion". In: KRIEGEL, U. (ed.) The Routledge Handbook of Franz Brentano and the Brentano School. New York: Routledge, 2017. pp. 216-221.

SCHAEFER, R. "The Madness of Franz Brentano: Religion, Secularisation and the History of Philosophy". History of European Ideas, Vol. 39, Nr. 4, pp. 541-560, 2013. SCHMIT, R. "Brentano et le positivisme". Archives de Philosophie, Vol. 65, Nr. 2, pp. 291-309, 2002.

SIMONS, P. "The four phases of philosophy: Brentano's theory and Austria's history". The Monist, Vol. 83, Nr. 1, pp. 68-88, 2000.

SPIEGELBERG, H. "The phenomenological movement. A historical introduction", Vol. 1. Den Haag: Marinus Nijhoff, 1965.

. "Phenomenology in Psychology and Psychiatry. A historical introduction".

Evanston: Northwestern University Press, 1972.

STUMPF, C. "Erinnerungen an Franz Brentano". In: KRAUS, O. (ed.). Franz Brentano. Zur Kenntnis seines Lebens und seiner Lehre. München: C.H. Becksche Verlagsbuchhandlung, 1919. pp. 87-149. 
. "Selbstdarstellung". In: SCHMIDT, R. (ed.). Philosophie der Gegenwart in Selbstdarstellungen. Leipzig: Felix Meiner Verlag, 1924. pp. 205-265.

TĂNĂSESCU, I. "Brentano - Comte - Mill: The Idea of Philosophy and Psychology as Science". Forthcoming.

TĂNĂSESCU, I. "Die Phasentheorie. Franz Brentano und Auguste Comte." BrentanoStudien, Vol. 15, Nr. 1, pp. 335-366, 2017.

TATARKIEWICZ, W. "Nineteenth century philosophy" Translation from C.A. Kisiel. Belmont: Wadsworth Publishing Company, 1973.

VOLPI, F. "War Franz Brentano ein Aristoteliker? Zu Brentanos und Aristoteles Konzeption der Psychologie als Wissenschaft." Brentano-Studien, Vol. 2, pp. 13-29, 1989. WERLE, J. M. "Franz Brentano und seine Schüler. Aspekte fruchtbarer und problematischer Beziehungen”. Brentano-Studien, Vol. 2, pp. 91-101, 1989. WILLARD, D. "Who needs Brentano? The wasteland of philosophy without its past". In: POLI, R. (ed.). The Brentano Puzzle. Vermont: Ashgate Publishing Company. Western Philosophy Series, 1998. pp. 15-43. 